University of Windsor

Scholarship at UWindsor

Mechanical, Automotive \& Materials

Department of Mechanical, Automotive \& Engineering Publications

Materials Engineering

$11-29-2017$

\title{
Energy efficiency and economic feasibility of an absorption air- conditioning system using wet, dry and hybrid heat rejection methods
}

\author{
Julia Aman \\ University of Windsor \\ Paul Henshaw \\ University of Windsor \\ David S-K Ting \\ University of Windsor
}

Follow this and additional works at: https://scholar.uwindsor.ca/mechanicalengpub

Part of the Energy Systems Commons

\section{Recommended Citation}

Aman, Julia; Henshaw, Paul; and Ting, David S-K. (2017). Energy efficiency and economic feasibility of an absorption air-conditioning system using wet, dry and hybrid heat rejection methods. International Journal of Environmental Studies.

https://scholar.uwindsor.ca/mechanicalengpub/7

This Article is brought to you for free and open access by the Department of Mechanical, Automotive \& Materials Engineering at Scholarship at UWindsor. It has been accepted for inclusion in Mechanical, Automotive \& Materials Engineering Publications by an authorized administrator of Scholarship at UWindsor. For more information, please contact scholarship@uwindsor.ca. 


\section{Energy efficiency and economic feasibility of an absorption air-conditioning system using wet, dry and hybrid heat rejection methods}

Julia Aman, Paul Henshaw \& David S.-K. Ting

To cite this article: Julia Aman, Paul Henshaw \& David S.-K. Ting (2017): Energy efficiency and economic feasibility of an absorption air-conditioning system using wet, dry and hybrid heat rejection methods, International Journal of Environmental Studies

To link to this article: https://doi.org/10.1080/00207233.2017.1396073

Published online: 29 Nov 2017.

Submit your article to this journal $\square$

Q View related articles ¿

View Crossmark data $\complement$ 


\title{
Energy efficiency and economic feasibility of an absorption air-conditioning system using wet, dry and hybrid heat rejection methods
}

\author{
Julia Aman, Paul Henshaw and David S.-K. Ting \\ Turbulence and Energy Laboratory, Centre for Engineering Innovation, University of Windsor, Windsor, Canada
}

\begin{abstract}
In tropical and sub-tropical regions, air-conditioning systems account for the greatest electricity consumption and high water use. Solardriven absorption cooling systems can conveniently reduce electricity consumption at need. The performance of this cooling system depends on the system's heat rejection. A simulation was performed for a $15 \mathrm{~kW}$ single effect ammonia-water absorption cooling system driven by low temperature thermal energy and with three different heat rejection methods (wet cooling, dry cooling, and hybrid cooling). This hybrid cooling system uses wet cooling on the absorber and dry cooling on the condenser. The system performance and economics of the chiller with these cooling methods were evaluated. The analysis showed that a wet cooling system has a higher system performance and water consumption compared to a dry cooling system, which has a high primary energy consumption with no water usage. In hot weather conditions and where there is scarcity of water, hybrid cooling can consume on average $41 \%$ less electrical energy than dry cooling and $49 \%$ less water than wet cooling and the payback period compared to a wet cooling system can be less than three years.
\end{abstract}

\section{KEYWORDS}

Absorption; air-conditioning; wet-cooling; dry-cooling; hybrid cooling; efficiency; cost

\section{Introduction}

In tropical and sub-tropical regions, modern cities are the main consumers of electricity and most of this energy is for air-conditioning systems in buildings. In the United Arab Emirates (UAE), $60 \%$ of the total electrical energy is consumed by building air-conditioning systems during summer [1]. Improving the efficiency of existing energy usage and using renewable energy resources are key to protect the environment. Renewable energy integration either alone or in hybrid systems can meet the growing energy demand and provide sustainable energies for the future [2]. For air-conditioning applications, conventional vapour compression systems are commonly used, which are driven by electrical energy. This causes stress in the generation and distribution systems during the peak load period in the summer. Thermally driven cooling systems are a sustainable energy technology that provides cooling by replacing electrically driven compressor chillers with thermally driven chillers. 
They are known to be technically feasible [3]. Solar thermal energy is a suitable option for providing this cooling comfort. For example, Australia, with the highest annual solar radiation in the world, can meet its total energy demand by solar thermal energy using an area approximately equal to its existing rooftops [4].

Thermal absorption cooling systems can be driven by waste heat or solar thermal energy. Such a system consists of a heat driven generator, a condenser, an evaporator, a solution heat exchanger and an absorber. While providing cooling, the condenser and the absorber of the absorption chiller produce heat that must be rejected: which is the same as for the condenser of a traditional vapour compression chiller. The performance of the absorption chiller depends on the heat rejection of the absorber as well as the condenser. Hence, it is crucial to consider efficient heat rejection methods and energy consumption of auxiliaries for the overall primary energy balance of this cooling system [5].

There are various heat rejection methods that can be applied for condenser and absorber cooling in absorption cooling systems. These include evaporative or wet (water) cooling towers, air or dry cooling, hybrid cooling (with both wet and dry cooling), geothermal heat sinks, and night radiative cooling [6]. Kummert et al. [7] compared the system performance and energy cost for a geothermal absorption chiller and a vapour compression chiller for providing space heating and cooling in three different cities in Canada. The system coefficient of performance (COP) is always higher for compression heat pump systems, but where electricity prices are relatively low (Vancouver and Montreal) the life cycle cost is higher for natural gas-driven absorption heat pump systems. Although wet cooling is preferable for better system performance for the heat rejection of the absorber and condenser in an absorption chiller, water consumption is dominant in this method. The statistics of water usage at the California Institute of Technology show that $40 \%$ of the water consumption is for the central air-conditioning system in the campus [8]. In most of the arid Southwest USA and subtropical regions where policy and cost require reduced water usage, an air-cooled condenser and absorber are necessary. In cities like Hong Kong, the building density is very high and, because of the climate, cooling is needed throughout the year [9]. The government in Hong Kong does not permit the use of fresh water for heat rejection in building/central air-conditioning applications [10]. But, in hot weather where water is available, both wet and dry cooling methods can be used in parallel in a hybrid system. When a cooling tower is used as a heat rejection method for absorption air-conditioning, the energy needed is accounted for in the primary energy balance. The effectiveness of dry-cooling and wet-cooling methods is determined by the minimum temperature that each heat rejection method can provide. The wet cooling methods use the evaporation process to reject the heat, based on the wet bulb temperature, whereas dry cooling depends on the ambient dry-bulb temperature [11].

An absorption air-conditioning system can be driven by a single-effect absorption chiller with a generator temperature varying from 60 to $120{ }^{\circ} \mathrm{C}$ [12]. The heat rejection for this system can be air-cooled or wet-cooled. As the performance of the absorption chiller depends on the absorber heat rejection, different studies of heat and mass transfer have been performed to improve the absorber efficiency, considering the expected high ambient temperature at the time of air conditioning use [13]. A wet-cooled single effect $\mathrm{LiBr}-\mathrm{H}_{2} \mathrm{O}$ absorption chiller has been studied and the efficiency was found to be higher at a higher dry bulb temperature because of the lower relative humidity at the high dry bulb temperature [14]. Asdrubali and Grignaffini performed an experiment using a single effect $\mathrm{LiBr}-\mathrm{H}_{2} \mathrm{O}$ absorption [15], and found the highest performance at a $70{ }^{\circ} \mathrm{C}$ generator temperature when 


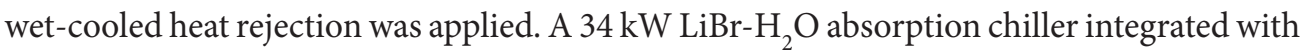
membrane distillation was simulated based on UAE weather conditions and the highest COP was 0.7 during the peak period of summer [16]. Some studies have been carried out for the performance of air-cooled $\mathrm{LiBr}-\mathrm{H}_{2} \mathrm{O}$ absorption chillers $[13,17,18]$. An ammonia-water absorption chiller is suitable for small-scale applications [12]. The SolarNext company in Germany introduced a $10 \mathrm{~kW}$ water cooled $\mathrm{NH}_{3}-\mathrm{H}_{2} \mathrm{O}$ absorption system for commercial air-conditioning applications that has a thermal coefficient of performance $\left(\mathrm{COP}_{\mathrm{th}}\right)$ of 0.63 at a $16^{\circ} \mathrm{C}$ chilled water temperature [19]. Many prototypes have been built for air-cooled $\mathrm{NH}_{3}-\mathrm{H}_{2} \mathrm{O}$ absorption chillers in order to analyse them experimentally. $\mathrm{Du}$ et al. [20] performed an experiment on a two-stage $2 \mathrm{~kW}$ air-cooled chiller and reported a $\mathrm{COP}_{\text {th }}$ of 0.21 and an electrical coefficient of performance $\left(\mathrm{COP}_{\mathrm{el}}\right)$ of 5.1 with $8{ }^{\circ} \mathrm{C}$ and $29{ }^{\circ} \mathrm{C}$ evaporator and air temperatures, respectively. Aprile et al. [21] found that a $2.5 \mathrm{~kW}$ double-effect air-cooled $\mathrm{NH}_{3}-\mathrm{H}_{2} \mathrm{O}$ chiller performed at a $\mathrm{COP}_{\text {th }}$ of 0.3 and $\mathrm{COP}_{\mathrm{el}}$ of 10 , at an air temperature of $30^{\circ} \mathrm{C}$, to provide $7^{\circ} \mathrm{C}$ chilled water.

In short, there have been many research and experimental studies to improve the system performance of absorption chillers with different heat rejection systems. The scarcity of clean water in arid and semi-arid regions makes it necessary to optimize primary energy and water consumption, correlated with system performance and economic index. To the authors' knowledge, no analyses have been conducted for the comparison of different cooling methods in absorption air-conditioning systems with respect to energy and economic analysis.

In this present work, a dynamic simulation model has been developed in TRNSYS 17 in order to evaluate the primary energy consumption as well as water usage for different cooling systems in a $15 \mathrm{~kW}$ absorption chiller at different operating conditions. Much research has been carried out for the simulation of $\mathrm{LiBr}-\mathrm{H}_{2} \mathrm{O}$ absorption chillers by TRNSYS 17 software [22-27]. This software is restricted only to the $\mathrm{LiBr}-\mathrm{H}_{2} \mathrm{O}$ absorption chiller [28] and the simulation is independent of thermodynamic properties of the absorbent-refrigerant solution and the internal thermodynamic cycle performance. To overcome these limitations of TRNSYS, a detailed thermodynamic analysis has been performed of a $15 \mathrm{~kW} \mathrm{NH}-\mathrm{H}_{2} \mathrm{O}$ absorption solar air-conditioning system within Engineering Equation Solver (EES) [29] and coupled with the simulation model of heat rejection systems in TRNSYS 17. As a result, the model describes the energy consumption by different auxiliaries, and their effects on the overall system performance based on thermodynamic analyses of this air-conditioning system. Additionally, an economic analysis has been developed, considering the capital investment and operating cost, and the penalty cost of $\mathrm{CO}_{2}$ emissions. Finally, energetic and economic analyses have been compared for different heat rejection methods.

\section{System analysis}

A model was developed for a $15 \mathrm{~kW}$ single effect $\mathrm{NH}_{3}-\mathrm{H}_{2} \mathrm{O}$ absorption chiller driven by solar thermal energy for the evaluation of primary energy consumption and the energy efficiency of the cooling system. This system was analysed with different heat rejection methods at different operating conditions. Figures 1 and 2 represent the schematics of single-effect absorption refrigeration systems with different heat rejection methods: Figure 1 for wet or dry cooling and Figure 2 for hybrid cooling. The model describes the thermodynamic process of the absorption cooling system in order to calculate the primary energy 


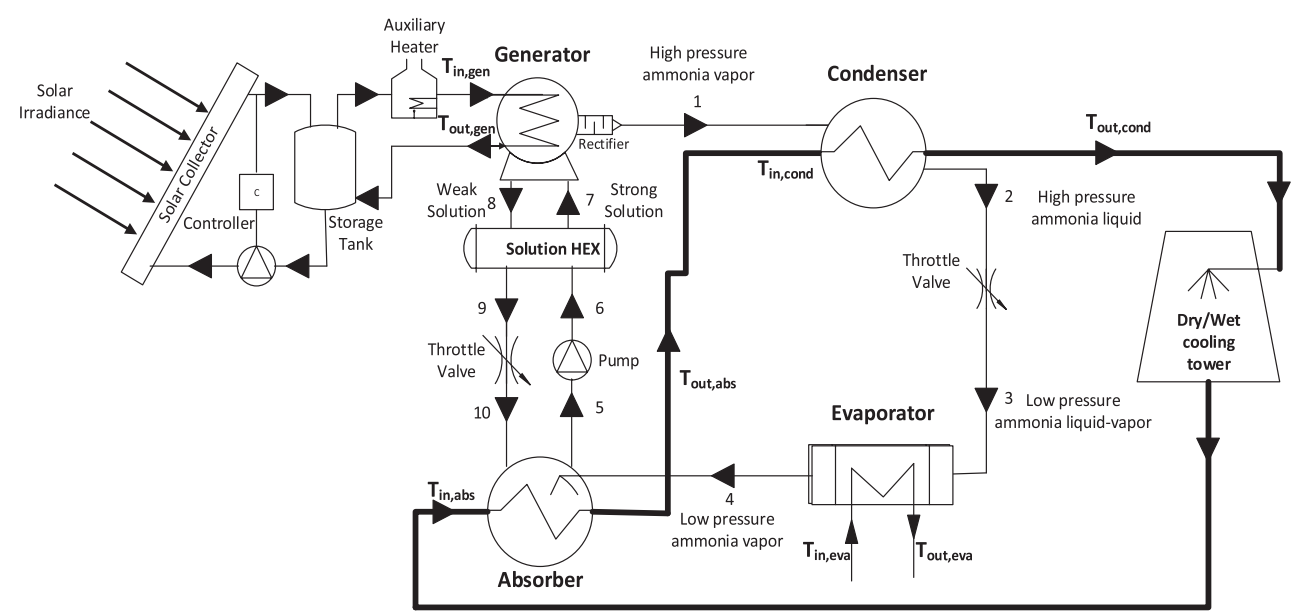

Figure 1. Schematic of a wet/dry cooled single-effect $\mathrm{NH}_{3}-\mathrm{H}_{2} \mathrm{O}$ absorption cooling system.

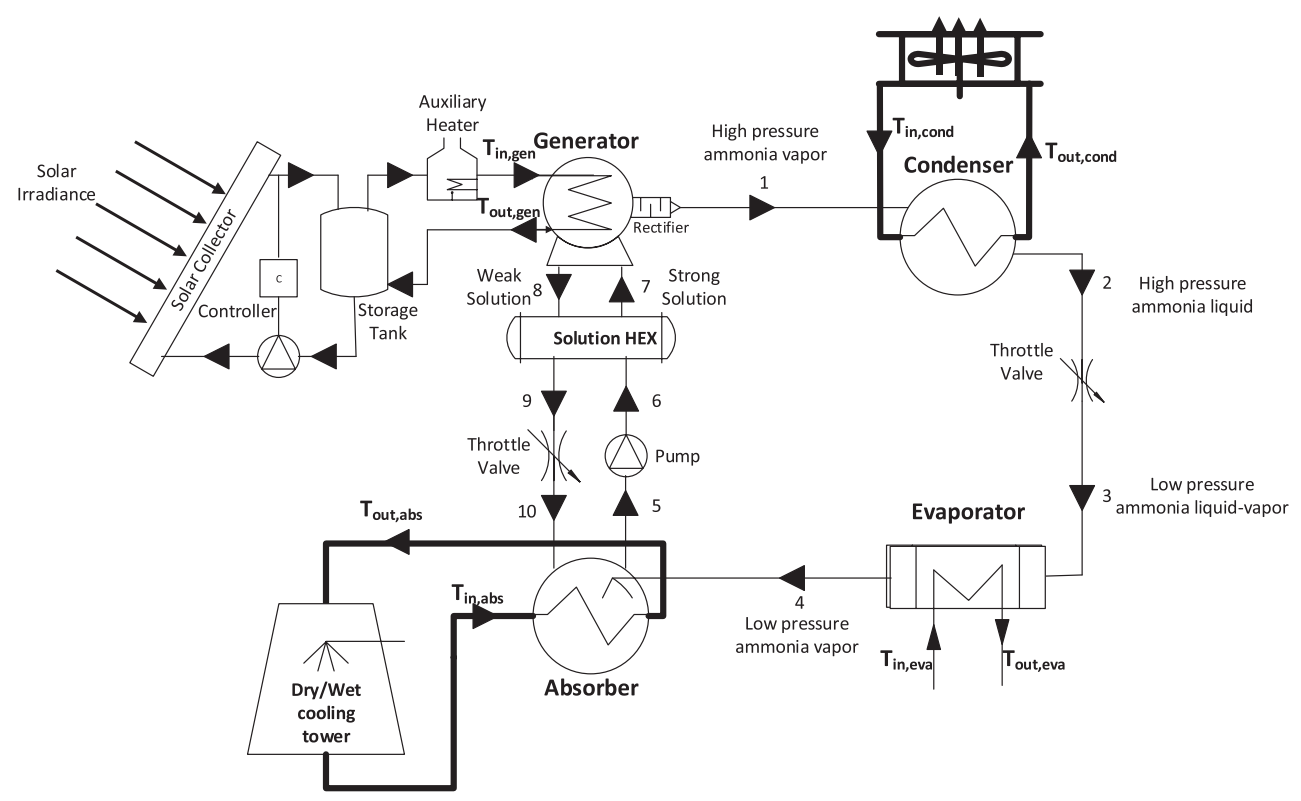

Figure 2. Schematic of a hybrid-cooled single-effect $\mathrm{NH}_{3}-\mathrm{H}_{2} \mathrm{O}$ absorption cooling system.

consumption of the absorption chiller and auxiliaries at different heat rejection systems. The system performance and primary energy efficiency are analysed in this model.

\subsection{Thermodynamic analysis}

Assuming that there are no heat losses, the rated energy supplied to the generator is:

$$
\dot{Q}_{\text {gen }}=\dot{m}_{w . \text { gen }} C_{p . w}\left(T_{\text {in, gen }}-T_{\text {out,gen }}\right)
$$


The cooling load of the evaporator, which was set to a constant $15 \mathrm{~kW}$ in this study, is:

$$
\dot{Q}_{\text {eva }}=\dot{m}_{w . \text { eva }} C_{p . w}\left(T_{\text {in,eva }}-T_{\text {out, eva }}\right)
$$

The temperature of the absorber and the condenser depends on the different heat rejection methods. The following equation yields the energy required for the absorber:

$$
\dot{Q}_{\mathrm{abs}}=\dot{m}_{w . \mathrm{abs}} C_{p . w}\left(T_{\text {out,abs }}-T_{\text {in,abs }}\right)
$$

The total energy balance of the absorption chiller can be calculated from the total heat gained by the system and the total heat rejected from the system, assuming no heat losses to the surroundings, and can be written as:

$$
\dot{Q}_{\mathrm{abs}}+\dot{Q}_{\text {cond }}=\dot{Q}_{\mathrm{gen}}+\dot{Q}_{\mathrm{eva}}
$$

By using Equations (1) to (4), the energy required by the condenser can be deduced.

The solution heat exchanger effectiveness can be evaluated by the following equation:

$$
\varepsilon_{\mathrm{HEX}}=\frac{T_{8}-T_{9}}{T_{8}-T_{6}}
$$

For pumping the solution from the absorber to the generator, the energy required by the pump of the absorption chiller can be defined by:

$$
\dot{W}_{\text {solp }}=\left(P_{6}-P_{5}\right) v_{6}
$$

The COP of an absorption cooling system can be defined in three different ways:

(a) The $\mathrm{COP}_{\text {th }}$ is the ratio of the cooling load to the heat input to the generator:

$$
\mathrm{COP}_{\mathrm{th}}=\frac{\dot{Q}_{\mathrm{eva}}}{\dot{Q}_{\mathrm{gen}}}
$$

(b) Considering the electrical energy consumption by the absorption chiller and auxiliaries including all pumps, fans and cooling tower, the $\mathrm{COP}_{\mathrm{el}}$ is:

$$
\mathrm{COP}_{\mathrm{el}}=\frac{\dot{\mathrm{Q}}_{\mathrm{eva}}}{\sum \dot{W}_{\mathrm{aux}}}
$$

(c) It is important to consider primary energy consumption by auxiliaries and the cooling tower when analysing the total performance of an absorption refrigeration system. The performance of the absorption cooling system can be defined as a primary energy ratio (PER) [27], which is the ratio of useful energy output to the primary energy (electrical and thermal energy) input. The primary energy input is considered as the total energy input to the system, which includes the total electrical energy consumption and the thermal energy supplied to the system and it is defined as: 


$$
\operatorname{PER}=\frac{\dot{Q}_{\mathrm{eva}}}{\dot{Q}_{\mathrm{gen}}+\sum \dot{W}_{\mathrm{aux}} \cdot \mathrm{PEF}_{\mathrm{el}}}
$$

where $\mathrm{PEF}_{\mathrm{el}}$ is the primary energy factor for electricity, equal to 3.36 [30].

\subsection{Economic analysis}

In order to evaluate the economic feasibility of different cooling methods in an absorption chiller, a simple cost analysis which includes capital and operating costs of the total cooling system was performed. As the operating cost is different in different regions owing to different electricity or water prices, two different countries - Canada and the UAE - were chosen for comparison in this cost analysis because of their differences in cooling demand, electricity and water costs. It was assumed that the air-conditioning period in any year is 4 months for Canada and the entire 12 months for the UAE. Since the cooling tower dominates the primary energy consumption and water usage, the cost of its energy usage is the primary factor for economic analysis. The investment costs of an absorption chiller and cooling tower are the major costs, so these were the only items considered for the capital cost investment (CI). Other component costs were not reflected in this study. The specific capital costs of wet cooling, dry cooling and hybrid cooling were considered to be $110 \mathrm{US} \$ / \mathrm{kW}, 134 \mathrm{US} \$ / \mathrm{kW}$ and $146 \mathrm{US} \$ / \mathrm{kW}$, respectively; values which were taken from regression analysis of different manufacturing data [31]. Hence, the major investment cost of an absorption cooling system was determined as:

$$
\mathrm{CI}_{\text {Total }}=\mathrm{CI}_{\mathrm{CH}}+\mathrm{CI}_{\mathrm{CT}}
$$

The operating cost $\left(C_{\text {op }}\right)$ of this cooling system includes the consumption of electrical energy $\left(C_{\mathrm{el}}\right)$, water $\left(C_{\mathrm{w}}\right)$ and can be can be calculated by the following equation:

$$
C_{\mathrm{op}}=C_{\mathrm{el}} \times c_{e}+C_{w} \times c_{w}
$$

where, $c_{e}$ and $c_{w}$ are the unit costs of electricity and water (including waste water) and were assumed to be $0.10 \mathrm{US} \$ / \mathrm{kWh}$ and $2.86 \mathrm{US} \$ / \mathrm{m}^{3}$ for Canada [32] and $0.044 \mathrm{US} \$ / \mathrm{kWh}$ and $2.95 \mathrm{US} \$ / \mathrm{m}^{3}$ for the UAE [33]. In a wet cooling tower, another major cost is the water treatment. In this analysis, the treatment is considered to occur every two weeks for the sump water and the water treatment cost was assumed $7.13 \mathrm{US} \$ / \mathrm{m}^{3}$ [34].

Although the wet cooling absorption chiller is thermodynamically more energy efficient than the dry cooling system, it may not be in terms of the combined energy and water cost. It is necessary to put in perspective the total cost (capital and operating) of different cooling systems for absorption chillers. Therefore, a simple payback period (SPBP) was calculated as an economic index of dry and hybrid cooling systems compared to a wet cooling system. In terms of environmental factors, $\mathrm{CO}_{2}$ emission is important and its cost was also included in this analysis. So, the SPBP of different cooling methods was assessed as follows:

$$
\operatorname{SPBP}=\frac{\left(\mathrm{CI}_{\text {total }}\right)_{\text {dry/hybrid }}-\left(\mathrm{CI}_{\text {total }}\right)_{\text {wet }}}{\left(C_{\text {op,wet }}-C_{\text {op,dry/hybrid }}\right)+\left(C_{\mathrm{CO}_{2} \text {,wet }}-C_{\mathrm{CO}_{2} \text {,dry/hybrid }}\right)}
$$


where,

$$
\mathrm{C}_{\mathrm{CO}_{2}}=\mathrm{C}_{\mathrm{el}} \times \mathrm{EF}_{\mathrm{CO}_{2}} \times c_{\mathrm{CO}_{2}}
$$

In Equation (13), $\mathrm{EF}_{\mathrm{CO} 2}$ is the $\mathrm{CO}_{2}$ emission factor for electricity production, and was assumed to be $0.856 \mathrm{~kg}$ of $\mathrm{CO}_{2} / \mathrm{kWh}$ [35] in Canada and $0.739 \mathrm{~kg}$ of $\mathrm{CO}_{2} / \mathrm{kWh}$ [36] in the UAE. $\mathrm{c}_{\mathrm{CO}_{2}}$ is the $\mathrm{CO}_{2}$ emission penalty cost of $0.01 \mathrm{US} \$$ per $\mathrm{kg}$ in both Canada and the $\mathrm{UAE}[37,38]$.

\section{Simulation procedure}

If the heat supply to the absorption chiller is constant, the thermal performance of the chiller depends on the outdoor temperature and the heat rejection temperature [18]. In this analysis, three variants of the absorption cooling system have been developed with different heat rejection methods: a wet cooling system, a dry cooling system or a hybrid cooling system. The thermodynamic properties of the absorbent-refrigerant solution of a $15 \mathrm{~kW}$ absorption chiller were determined using equations in Aman, Henshaw \& Ting [12] and calculated in EES [29]. A dynamic simulation model for different cooling towers was developed by using the energy simulation tool TRNSYS 17 [28]. Based on the required outlet temperature of the cooling tower, which was the inlet temperature of the absorber cooling water in the chiller, the amount of heat rejection and energy consumption by variant cooling towers was determined using this software. The primary energy balance and the performance of the absorption chiller were then calculated by solving Equations (1) to (9) in EES. Figure 3 shows the simulation procedure of this analysis. The simulation started with the input of the required refrigerant absorber temperature $\left(T_{\mathrm{abs}}\right)$ in EES which determined the $T_{\text {in,abs }}, T_{\text {out,cond }}$ and refrigerant temperature in the condenser $\left(T_{\text {cond }}\right)$ by using an internal heat exchanger efficiency of $80 \%$. The $T_{\text {cond }}$ determined the chiller system pressure which was used to calculate the refrigerant concentration at the absorber temperature in the absorber. Then the energy balance of the chiller was calculated. In TRNSYS, $T_{\text {in,abs }}$ was input as the target temperature. To achieve the target $T_{\text {in,abs, }}$ the flow rate of water in wet cooling or the fan power in dry cooling were varied. When the targeted $T_{\text {in,abs }}$ was reached, the auxiliary energy consumption, fan power, water loss from evaporation in wet cooling and heat rejection were calculated. These results from TRNSYS were used in EES to calculate the efficiency of the system.

In TRNSYS, in order to simulate the wet cooling tower and dry cooling tower, type $51 \mathrm{~b}$ and type511 were used, respectively. Each cooling method was used separately for the heat rejection of the absorber and condenser loop. For hybrid cooling, type 51b was used for absorber cooling and type 511 was used for condenser cooling to optimize the absorption system performance with minimum water usage. The water flow rate of the wet cooling tower and the electrical energy consumption rates by the fan of different cooling modes were determined by TRNSYS. Table 1 shows other electrical energy consuming devices of the absorption chiller.

As the weather data were not used in this analysis, Table 2 shows the assumptions of the dry-bulb and wet-bulb temperatures with respect to absorber temperature. 


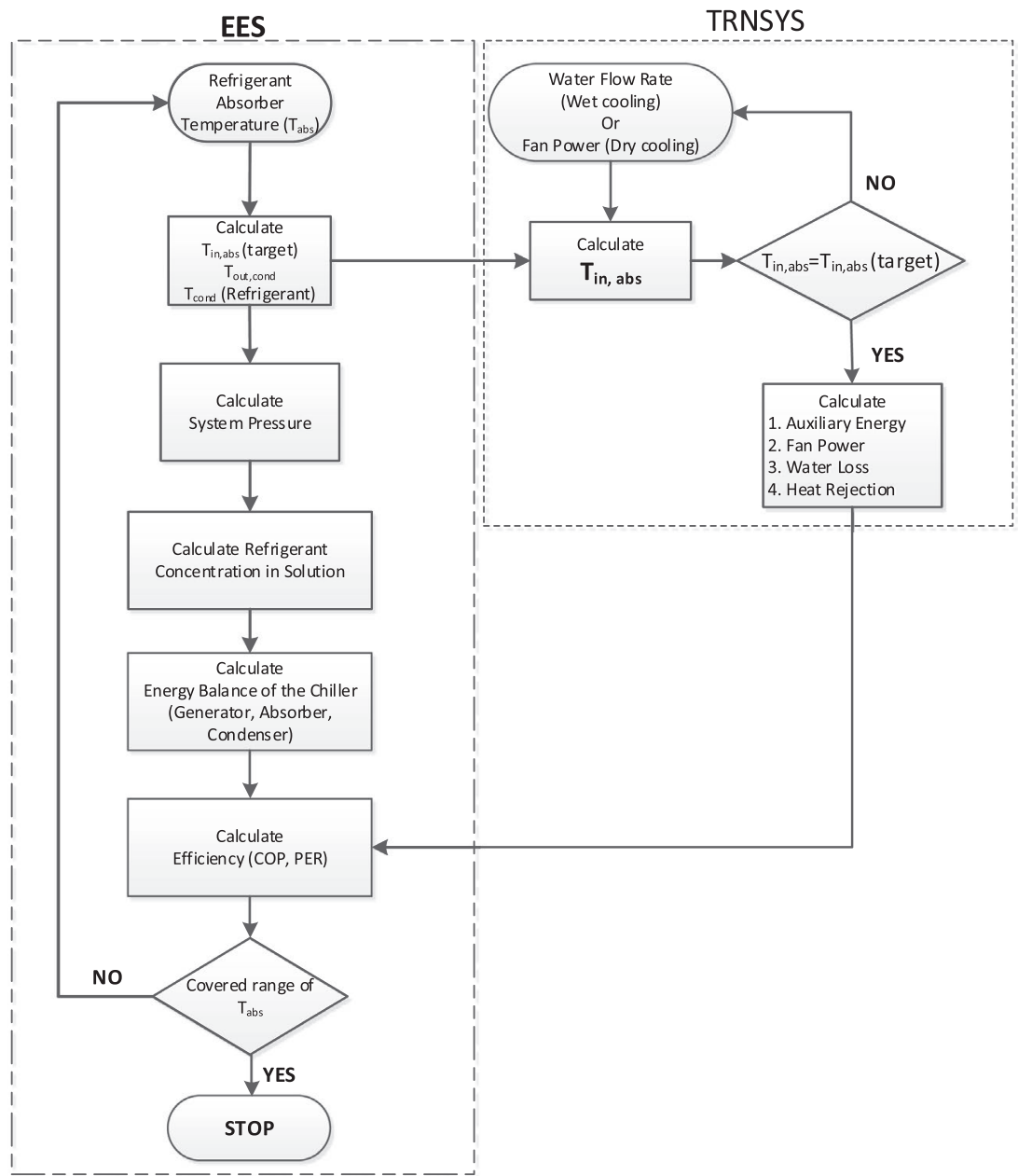

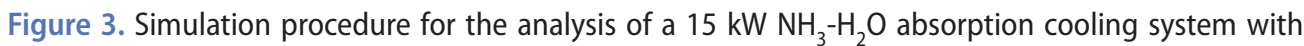
different heat rejection methods.

Table 1. Electrical energy consumption by pumps of a $15 \mathrm{~kW}$ absorption cooling system [2].

\begin{tabular}{lcc}
\hline Components & Nominal volume flow $\left(\mathrm{m}^{3} / \mathrm{h}\right)$ & Required electrical energy $(\mathrm{W})$ \\
\hline Solution pump of absorption chiller & 5.0 & 300 \\
Absorption/Condenser Auxiliary Pump & 10.0 & 1100 \\
Generator Auxiliary Pump & 2.0 & 56 \\
Evaporator Auxiliary Pump & 1.9 & 52 \\
\hline
\end{tabular}

Table 2. Variation of dry-bulb and wet-bulb temperature with respect to absorber temperature.

\begin{tabular}{lccc}
\hline Absorber temperature, ${ }^{\circ} \mathrm{C}$ & Wet-bulb temperature, ${ }^{\circ} \mathrm{C}$ & Dry-bulb temperature, ${ }^{\circ} \mathrm{C}$ & Relative humidity \\
\hline 20 & 17 & 18 & 91 \\
25 & 18 & 20 & 83 \\
30 & 21 & 25 & 71 \\
35 & 23 & 30 & 56 \\
40 & 25 & 35 & 45 \\
\hline
\end{tabular}




\subsection{Wet cooling tower (Type51b)}

Two input parameters need to be defined in this cooling tower: the mass transfer constant and the mass transfer exponent. The mass transfer constant is the ratio of water mass flow rate to air mass flow rate in the cooling tower and was set at 1.2 [23]. The mass transfer exponent was set at -0.65 according to a guideline of the American Society of Heating, Refrigerating and Air-Conditioning Engineers (ASHRAE) [39]. Table 3 shows the input parameters of this cooling system.

The outlet temperature of the cooling tower, which is the inlet water temperature of the absorber $\left(T_{\text {in,abs }}\right)$ (shown in Figure 1 ), was adjusted by varying the water flow rate while running the fan at constant speed until the target $T_{\text {in,abs }}$ was achieved. The water flow rate, the heat rejection and water consumption from evaporation were determined from the simulation results of the cooling tower. The electrical energy consumption by this cooling tower was calculated by the power consumption of the fan and the auxiliary pump.

\subsection{Dry cooling tower (Type511)}

The TRNSYS fluid cooler dry cooling device was used to simulate a dry cooling system for this absorption chiller. Water was used as the heat exchanging fluid between the absorber/ condenser and the dry cooler. In order to achieve the required absorber/condenser temperature, the fan speed of the cooler was controlled by varying the fan power. Table 4 shows the input parameters for this cooling tower.

\section{Hybrid cooling}

A hybrid cooling system was considered in order to conserve water and to achieve the optimum performance of this absorption cooling system. The performance of the chiller depends more on the absorber temperature than the condenser temperature when other parameters are constant. This is because the absorbent-refrigerant concentration ratio in the absorber strongly depends on the absorber temperature. Therefore, in hybrid cooling, a wet cooling tower (type 51b) was used for rejection of heat from the absorber by varying the fan speed while the water flow was kept at $0.8 \mathrm{~kg} / \mathrm{s}$. Unlike the case where only wet or dry cooling was used, the condenser temperature was fixed at $40^{\circ} \mathrm{C}$ by air-cooling, as shown in Figure 2, but the absorber temperature was varied. In this condition, the refrigerant was directly cooled by the fin tube heat exchanger in type 511 with forced air, so no external water was needed for this cooling. As a result, in hot weather conditions, the maximum system performance can be achieved by lowering the absorber temperature with minimum water usage.

Table 3. Type51b: Input variables for cooling tower.

\begin{tabular}{lc}
\hline Parameters & Input \\
\hline Water inlet temperature & $T_{\text {out.cond }}{ }^{\circ} \mathrm{C}$ \\
Inlet water flow rate, $\mathrm{kg} / \mathrm{s}$ & $0.33-3.63$ \\
Dry-bulb temperature, ${ }^{\circ} \mathrm{C}$ & $20-35$ \\
Wet-bulb temperature, ${ }^{\circ} \mathrm{C}$ & $18-25$ \\
Sump make-up temperature, ${ }^{\circ} \mathrm{C}$ & 25 \\
Relative fan speed for cell & 1 \\
\hline
\end{tabular}


Table 4. Type511: Input variables for cooling tower.

\begin{tabular}{lc}
\hline Parameters & Input \\
\hline Inlet fluid temperature, ${ }^{\circ} \mathrm{C}$ & $30-45$ \\
Inlet fluid flow rate, $\mathrm{kg} / \mathrm{S}$ & 0.5 \\
Set point temperature, ${ }^{\circ} \mathrm{C}$ & $T_{\text {abs }}$ \\
Surrounding temperature, ${ }^{\circ} \mathrm{C}$ & $19-35$ \\
Rated fan capacity & variable \\
\hline
\end{tabular}

\section{Results and analysis}

\subsection{Thermodynamic performance}

Table 5 shows the energy flows in each component of a $15 \mathrm{~kW}$ absorption air-conditioning system operating at $80^{\circ} \mathrm{C}$ generator, $40{ }^{\circ} \mathrm{C}$ condenser, $35^{\circ} \mathrm{C}$ absorber and $6{ }^{\circ} \mathrm{C}$ evaporator temperatures to provide $10^{\circ} \mathrm{C}$ chilled water $\left(T_{\text {out,eva }}\right)$ with an $80 \%$ heat exchanger effectiveness.

As electrical energy consumption is one criterion to evaluate the advantages of absorption chillers, Figure 4 shows the $\mathrm{COP}_{\mathrm{el}}$ of the $15 \mathrm{~kW}$ absorption chiller with different modes of heat rejection. Here, the analysis revealed that this $15 \mathrm{~kW}$ ammonia-water cooling system can operate only up to $40^{\circ} \mathrm{C}$ absorber temperature, at which temperature the absorber absorbs barely sufficient absorbent (assuming a $45^{\circ} \mathrm{C}$ condenser temperature) to provide $15 \mathrm{~kW}$ cooling in the evaporator under the operating conditions of $80{ }^{\circ} \mathrm{C}$ generator and $6{ }^{\circ} \mathrm{C}$ evaporator temperatures, respectively. Figure 4 shows that the $\mathrm{COP}_{\mathrm{el}}$ increased with increasing absorber/condenser temperature for all modes of operation. At higher absorber/ condenser temperatures, the relative humidity was less, so less fan power was required for the heat rejection by the cooling tower for cooling the absorber/condenser at increased temperature. Note that the $\mathrm{COP}_{\mathrm{el}}$ reached 8.05 in the wet cooling mode versus 5.2 for the dry cooling mode at $40{ }^{\circ} \mathrm{C}$ absorber temperature. In the wet cooling tower, the heat rejection occurred by the combination of heat and mass transfer. For this simulation with a wet cooling tower, the fan speed was constant but the water flow rate was controlled to achieve the required outlet temperature from the tower.

Increasing the water flow rate increases the water surface area exposed to the air. This increases the evaporation of water, which in turn increases the cooling rate of water in the tower. Therefore, the heat rejection depends on the water flow rate. In this cooling tower, the evaporation of water was the main mode of heat removal. Hence, less electrical energy was needed for the same amount of heat rejection compared to other cooling methods. As a result, a high $\mathrm{COP}_{\mathrm{el}}$ was obtained by this cooling tower. In contrast, the fan speed was controlled for the convection heat rejection in the dry cooling tower, which required a high volume of air to be moved to create the necessary heat transfer. This accounted for the high electrical energy consumption by the fan. As a result, the $\mathrm{COP}_{\mathrm{el}}$ of the dry cooling mode was

Table 5. Energy flow rate of each component of $15 \mathrm{~kW} \mathrm{NH}_{3}-\mathrm{H}_{2} \mathrm{O}$ absorption air-conditioning system.

\begin{tabular}{lc}
\hline Parameters & $\mathrm{kW}$ \\
\hline Generator, $Q_{\text {gen }}$ & 29.57 \\
Condenser, $Q_{\text {cond }}$ & 17.02 \\
Evaporator, $Q_{\text {eva }}$ & 15.00 \\
Absorber, $Q_{\text {abs }} Q_{C T}$ & 27.55 \\
Cooling Tower, $Q_{C T}$ & 44.84 \\
\hline
\end{tabular}




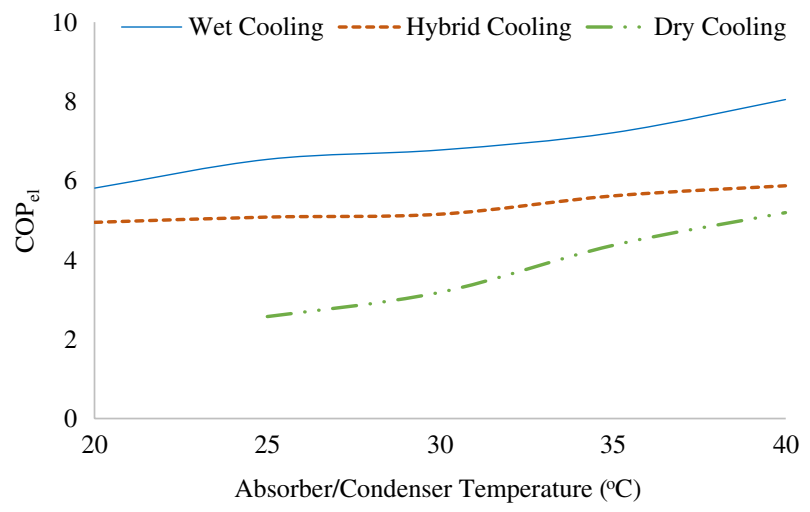

Figure 4. Electrical COP of $15 \mathrm{~kW} \mathrm{NH}_{3}-\mathrm{H}_{2} \mathrm{O}$ absorption cooling system with different heat rejection methods at $T_{\text {gen }}=80^{\circ} \mathrm{C}, T_{\text {eva }}=6^{\circ} \mathrm{C}$.

the lowest compared to the other two modes of operation. In the hybrid cooling system, the wet and dry cooling tower were in parallel. Therefore, the electrical energy consumption was intermediate between those of the other two cooling systems.

Figure 5 compares the PER and $\mathrm{COP}_{\text {th }}$ of different modes of heat rejection. The absorber system thermal performance decreased as the absorber/condenser temperature increased for all modes of operation. Increasing the absorber temperature adversely affected the refrigerant vapour absorption in the absorber. Therefore, to supply a constant cooling load in the evaporator, the thermal load of the generator had to increase. At the same time, increasing the condenser temperature increased the system pressure, which increased the thermal load in the generator as well. These two effects were responsible for lowering the COP ${ }_{\text {th }}$.

In wet or dry cooling modes, the condenser temperature depended on the absorber temperature as the outlet temperature of the absorber cooling water $\left(T_{\text {out,abs }}\right)$ is the inlet temperature of the condenser coolant $\left(T_{\text {in.cond }}\right)$ for heat rejection, as shown in Figure 1. So, the condenser temperature was always higher than the absorber temperature. But the absorption chiller itself operated through the same cycle and at the same absorber/condenser temperatures for the wet cooling mode or the dry cooling mode. As a result, there was no variation of the thermal performance $\left(\mathrm{COP}_{\mathrm{th}}\right)$ by wet and dry cooling methods with

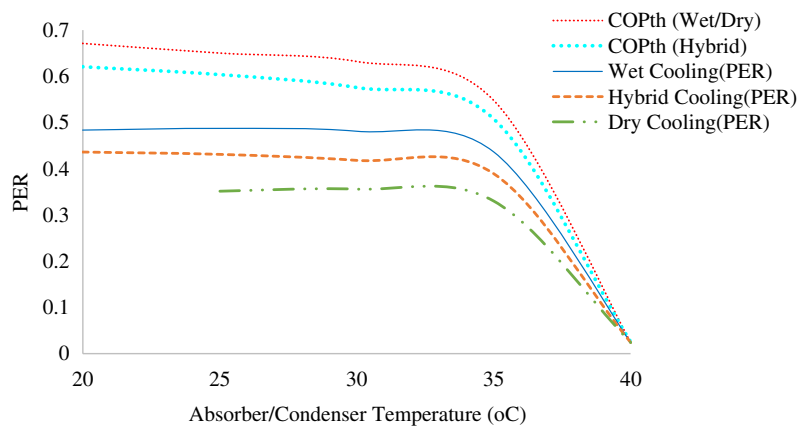

Figure 5. Primary Energy Ratio (PER) of $15 \mathrm{~kW} \mathrm{NH} \mathrm{H}_{3}-\mathrm{H}_{2} \mathrm{O}$ absorption cooling system with different heat rejection methods at $T_{\text {gen }}=80^{\circ} \mathrm{C}, T_{\text {eva }}=6^{\circ} \mathrm{C}$. 
respect to absorber/condenser temperatures. In the wet cooling mode, the primary energy consumption, including thermal and electrical, was lower than all other cooling modes and it increased as the absorber temperature rose; therefore the PER decreased. In contrast, a slight increase of PER was observed for the dry cooling mode as the absorber temperature rose from 25 to $35^{\circ} \mathrm{C}$. At higher absorber temperature, less heat rejection was observed that required less fan power which meant a higher PER. Although the thermal load was the same as that for the wet cooling system, the electrical energy consumption by the fan for the dry cooling tower was higher, so the total primary energy consumption was much greater compared to the wet cooling mode. As a result, the overall PER of dry cooling was lower than that in the wet cooling mode. As the generator thermal load increased above $35^{\circ} \mathrm{C}$ absorber temperature for all cooling modes, so the PER dropped for all.

For the hybrid cooling mode, it was observed that the $\mathrm{COP}_{\text {th }}$ was lower than the wet/dry cooling mode. In this cooling method, the condenser was cooled by dry cooling and kept at a constant $40{ }^{\circ} \mathrm{C}$, and the absorber temperature was controlled by wet cooling. Therefore, increasing the absorber temperature decreased the refrigerant absorption in the absorber at a high constant condenser temperature that resulted in an increased system pressure. As a result, the thermal load of the absorber and the generator increased, hence lowering the $\mathrm{COP}_{\text {th }}$ for this cooling method compared to the other two modes. As a dry cooling tower was used for the condenser to maintain a high temperature, so the electrical energy consumption by the fan was less than that of the dry cooling mode; therefore, the PER was intermediate for this cooling method. Over the range of temperatures simulated, the average PER of the hybrid system was 13\% lower than for wet cooling and $20 \%$ higher than the dry cooling mode of operation, which compensated for the $8 \%$ lower $\mathrm{COP}_{\text {th }}$ compared to the other two cooling systems.

\subsection{Energy and economic performance}

Figure 6 shows the electrical energy and water consumption rates of the three different cooling methods. The highest electrical energy consumption was observed in the dry cooling mode, which decreased rapidly as the absorber/condenser temperature increased, but it was on average $54 \%$ higher than that for the wet cooling mode. The required electrical energy of the wet cooling system was the lowest of all cooling modes and was almost constant as the

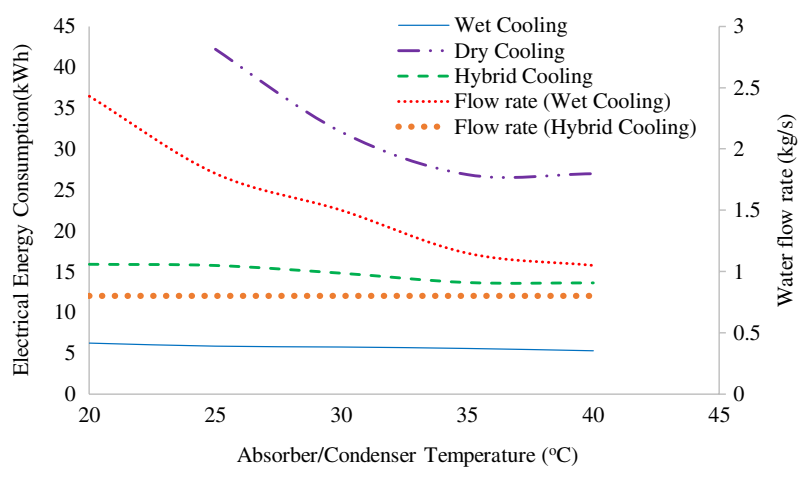

Figure 6. Electrical energy consumption and water flow rate of $15 \mathrm{~kW} \mathrm{NH}_{3}-\mathrm{H}_{2} \mathrm{O}$ absorption cooling system with different heat rejection methods at $T_{\text {gen }}=80^{\circ} \mathrm{C}, T_{\text {eva }}=6^{\circ} \mathrm{C}$. 
temperature rose. In contrast, the water consumption was highest in this mode of cooling. The hybrid cooling system demonstrated a trade-off between electrical energy and water consumption. In this cooling method, the water flow rate was kept constant while the fan speed was controlled to circulate the atmospheric air for the evaporation of water in the wet cooling tower for the absorber cooling. This was done to keep the water consumption low, while providing the same heat rejection as the wet cooling tower. A dry cooling tower was used for the condenser cooling in the hybrid cooling method. As a result, the average electrical energy consumption of the hybrid cooling method was $22 \%$ higher than the wet cooling mode but $41 \%$ lower than the dry cooling mode. This hybrid cooling used $49 \%$ less water compared to the wet cooling mode of operation.

Figures 7 and 8 show the electricity and water consumption per year using different cooling methods, to provide $15 \mathrm{~kW}$ cooling in Canada and the UAE. Table 6 summarises the thermal performance, PER and economic performance of these cooling systems. When comparing the electricity and water consumption and their costs between these two countries, it can be seen that the electricity and water consumption in the UAE are higher than in Canada by 3 times and 1.95 times, respectively. Because of the weather in the UAE, air-conditioning is required all the year round; whereas in Canada, the air-conditioning needs to run only four months. In contrast, the total cost of this electricity in the UAE is only 1.3 times higher as the unit price of electricity in the UAE is 2.7 times less than in Canada. In terms of water cost, the UAE pays 2.02 times more than Canada.

The SPBP in Table 6 was calculated to compare the economic benefit of dry and hybrid cooling over wet cooling methods. The capital cost of the wet cooling system was less than the other two methods and the thermal performance and PER were also higher for the wet cooling system. But, the operating cost of a wet cooling system is higher than the dry cooling system because of the high water cost and water treatment cost. The analysis reveals that although the dry cooling system had a lower PER and a higher capital cost, from an economic point of view, the cost can be paid back within 1 year over the wet cooling system. Therefore, the dry cooling tower can replace the wet cooling tower where the water cost is high and the use of fresh water is forbidden for air-conditioning applications. Owing to the high dry bulb temperatures in some locations like southern California and Nevada, dry cooling is not, however, feasible [8]. In such a case, the hybrid cooling system can be used to trade-off between water consumption

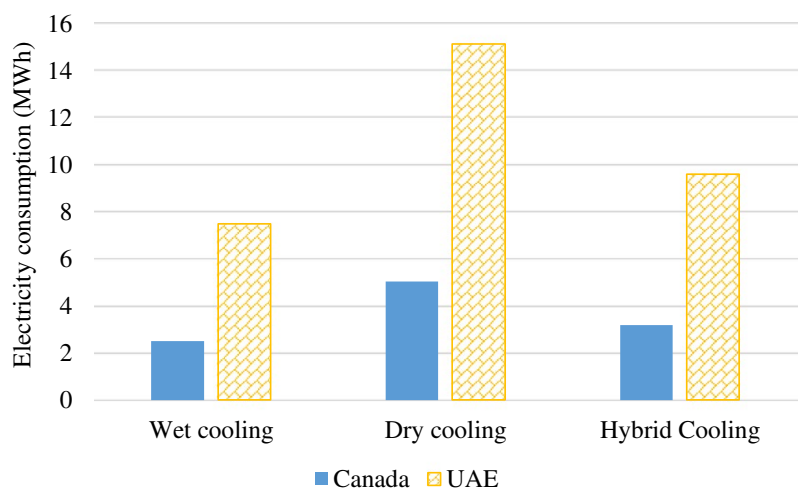

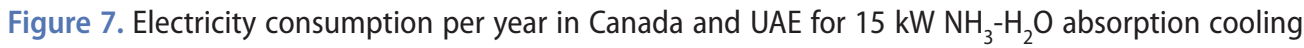
system with different heat rejection methods. 


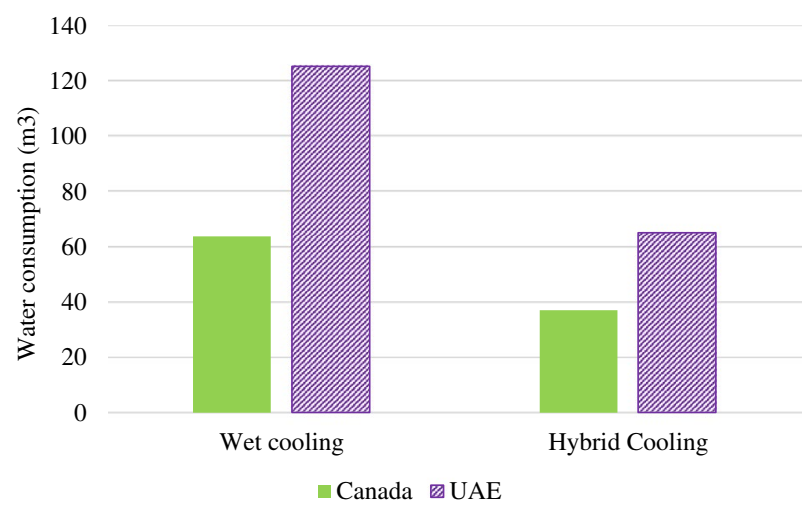

Figure 8. Water consumption per year in Canada and UAE for $15 \mathrm{~kW} \mathrm{NH}_{3}-\mathrm{H}_{2} \mathrm{O}$ absorption cooling system with wet and hybrid heat rejection methods.

and primary energy consumption. The total cost of hybrid cooling in this situation can be recovered within 2.9 years as a result of less water consumption compared to wet cooling. In contrast, in the UAE, the payback periods for dry and hybrid cooling systems over wet cooling are lower than in Canada as the electricity price is fairly low compared to the water price.

\section{Conclusion}

The aim of this study was to show how water usage and primary energy consumption of a $15 \mathrm{~kW} \mathrm{NH} \mathrm{H}_{3}-\mathrm{H}_{2} \mathrm{O}$ absorption cooling system could be reduced with different heat rejection methods. The primary energy and water usage for the best performance of the chiller, then the thermal, electrical and primary energy efficiency as well as cost effectiveness of wet cooling, dry cooling and hybrid cooling heat rejection methods of this absorption chiller have been investigated. A dynamic simulation model of different cooling methods was developed in TRNSYS software to estimate their electrical energy and water consumption. The thermodynamic properties of the refrigerant-absorbent solution and energy balance of the absorption chiller were calculated in EES to determine the efficiencies of this absorption cooling system.

The analysis reveals that the dry cooling method offers the highest potential for reducing the water consumption and best economic index for its operation. In contrast, the wet cooling method has the lowest primary energy consumption but a higher amount of water consumption and a higher operating cost. The hybrid cooling method uses the wet and dry cooling methods in parallel. With an average $8 \%$ lower thermal efficiency, this hybrid system can reduce water consumption by $49 \%$ and primary energy consumption by $41 \%$ compared to wet and dry cooling methods, respectively. The efficiency of this cooling method can return its cost within 2.9 years compared to the wet cooling method.

Finally, the analysis in this paper indicates that a wet cooling absorption system can be replaced by a dry cooling system at the same thermal efficiency where there is scarcity of water or the cost of water is high. Hybrid cooling is the best trade-off between primary energy and water usage in hot weather conditions. Overall, the analytical methods of this study provide clear thermo-economic guidance for choosing a suitable cooling method that can be used for absorption air-conditioning systems. 


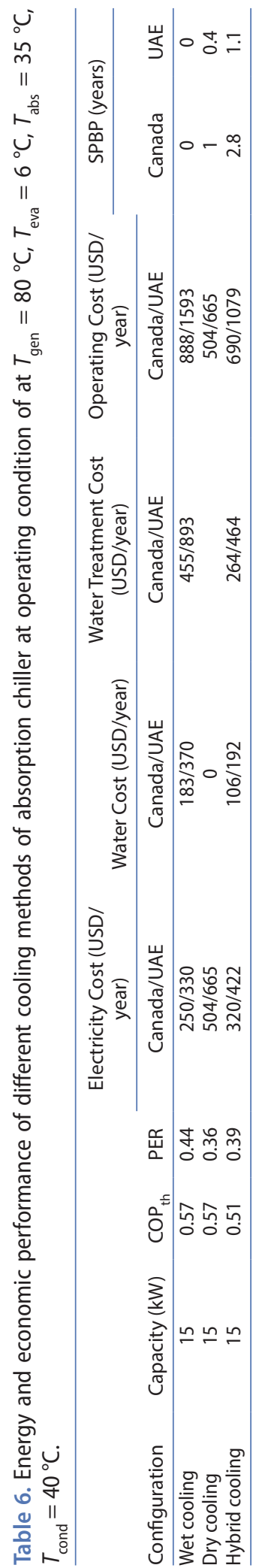




\section{Nomenclature}

CI capital investment cost (US\$)

$\mathbf{C O P}_{\text {th }}$ thermal coefficient of performance

$\mathrm{COP}_{\mathrm{el}}$ electrical coefficient of performance

$\mathrm{C}_{\mathrm{p}} \quad$ specific heat at constant pressure (kJ/kg.K)

c cost (US\$/unit)

C consumption

m mss flow rate $(\mathrm{kg} / \mathrm{s})$

P Pressure $(\mathrm{kPa})$

PER primary energy ratio

Q heat load (kW)

SPBP simple payback period (year)

T temperature $(\mathrm{K})$

US\$ USA dollars

$\dot{\mathrm{W}} \quad$ work done $(\mathrm{kW})$

$\varepsilon_{\text {HEX }} \quad$ heat exchanger effectiveness

$\boldsymbol{v} \quad$ refrigerant specific volume $\left(\mathrm{m}^{3} / \mathrm{kg}\right)$

\section{Subscripts}

$\begin{array}{ll}\text { abs } & \text { absorber } \\ \text { cond } & \text { condenser } \\ \text { CH } & \text { chiller } \\ \text { CT } & \text { cooling tower } \\ \text { DCT } & \text { dry cooling tower } \\ \text { el } & \text { electrical } \\ \text { eva } & \text { evaporator } \\ \text { gen } & \text { generator } \\ \text { HCT } & \text { Hybrid cooling tower } \\ \text { i } & \text { component } \\ \text { in } & \text { inlet } \\ \text { l } & \text { quid } \\ \text { out } & \text { outlet } \\ \text { p } & \text { pump } \\ \text { ref } & \text { reference } \\ \text { sol } & \text { solution } \\ \text { th } & \text { thermal } \\ \text { w } & \text { water } \\ \text { WCT } & \text { wet cooling tower } \\ \text { WT } & \text { water treatment }\end{array}$

\section{Acknowledgements}

This work is made possible by the Natural Science and Engineering Research Council of Canada. 


\section{Disclosure statement}

No potential conflict of interest was reported by the authors.

\section{References}

[1] Mokhtar, M., Ali, M.T., Brauniger, S., Afshari, A., Sgouridis, S., Armstrong, P. and Chiesa, M., 2010, Systemetic comprehensive techno-economic assessment of solar cooling technologies using location-specific climate data. Applied Energy, 87, 3766-3778.

[2] Shafiullah, G.M., 2016, Hybrid renewable energy integration (HREI) system for subtropical climate in Central Queensland, Australia. Renewable Energy, 96, 1034-1053.

[3] Zhai, X.Q. and Wang, R.Z., 2009, A review for absorption and adsorption solar cooling systems in China. Renewable and Sustainable Energy Reviews, 13, 1523-1531.

[4] Lovegrove, K., Dennis, M., 2006, Solar thermal energy systems in Australia. International Journal of Environmental Studies, 63(6), December, 791-802.

[5] Eicker, U., Dalibard, A. and Pesch, R., 2012, Heat rejection and primary energy efficiency of solar driven absorption cooling systems. International Journal of Refrigeration, 35, 729-738.

[6] Eicker, U. and Dalibard, A., 2011, Photovoltaic-thermal collectors for night radiative cooling of buildings. Solar Energy, 85, 1322-1335.

[7] Kummert, M., Bernier, M., Costa, A., Paris, J., 2007, A comparison between geothermal absorption and compression heat pumps for space conditioning. International Journal of Environmental Studies, 64(4), August, 467-487.

[8] Chang Sub Kim, 2008, Increasing Cooling Tower Water Efficiency (California Institute of Technology). Available online at: https://www.sustainability.caltech.edu/documents/33-chang sub_final_paper.pdf (accessed April 2016).

[9] Gang, W., Wang, S., Gao, D. and Xiao, F., 2015, Performance assessment of district cooling systems for a new development district at planning stage. Applied Energy, 1140, 33-43.

[10] Yik, F.W.H., Burnett, J. and Prescott, I., 2001, Predicting air-conditioning energy consumption of a group of buildings using different heat rejection methods. Energy Building, 33, 151-166.

[11] Turchi, C.S., Wagner, M.J., Kutscher, C.F., 2010, Water Use in Parabolic Trough Power Plants: Summary Results from WorleyParsons' Analyses, NREL (National laboratory of the U.S. Department of Energy, Technical Report NREL/TP-5500-49468, December 2010).

[12] Aman, J., Henshaw, P. and Ting, D.S.-K., 2014, Residential solar air conditioning: Energy and exergy analyses of an ammonia-water absorption cooling system. Applied Thermal Engineering, 62, 424-432.

[13] Izquierdo, M., Lizarte, R., Marcos, J.D. and Gutie' rrez, G., 2008, Air conditioning using an aircooled single effect lithium bromide absorption chiller: Results of a trial conducted in Madrid in August 2005. Applied Thermal Engineering, 28, 1074-1081.

[14] Syed, A., Izquierdo, M., Rodríguez, P., Maidment, G., Missenden J., Lecuona, A., Tozer, R., 2005, A novel experimental investigation of a solar cooling system in Madrid. International Journal of Refrigeration, 28, 859-871.

[15] Asdrubali, F. and Gignaffini, S., 2005, Evaluation of the performances of a $\mathrm{H}_{2} \mathrm{O}-\mathrm{LiBr}$ absorption refrigerator under different service conditions. International Journal of Refrigeration, 28, 489-497.

[16] Mohan, G., Kumar, N.T.U., Pokhrel, M.K. and Martin, A., 2016, A novel solar thermal polygeneration system for sustainable production of cooling, clean water and domestic hot water in United Arab Emirates: Dynamic simulation and economic evaluation. Applied Energy, 167, 173-188.

[17] Kim, D.S. and Infante Ferreira, C.A., 2009, Air-cooled LiBr-water absorption chillers for solar air conditioning in extremely hot weathers. Energy Conversion Manage, 50, 1018-1025.

[18] Palaci'n, F. and Monne', C., Alonso, S., 2011, Improvement of an existing solar powered absorption cooling system by means of dynamic simulation and experimental diagnosis. Energy, 36, 4109-4118.

[19] Jakob, U., Pink, W., 2007, Development and investigation of an ammonia/water absorption chiller - chillii_ PSC - for a solar cooling system. In: Proceedings of the 2nd International Conference Solar Air-conditioning, Tarragona, Spain, pp. 440-445. 
[20] Du, S., Wang, R.Z., Lin, P., Xu, Z.Z., Pan, Q.W. and Xu, S.C., 2012, Experimental studies on an aircooled two-stage $\mathrm{NH}_{3}-\mathrm{H}_{2} \mathrm{O}$ solar absorption air-conditioning prototype. Energy, 45, 581-587.

[21] Aprile, M., Toppi, T., Guerra, M. and Motta, M., 2015, Experimental and numerical analysis of an air-cooled double-lift $\mathrm{NH}_{3}-\mathrm{H}_{2} \mathrm{O}$ absorption refrigeration system. International Journal of Refrigeration, 50, 57-68.

[22] Shirazi, A., Taylor, R.A., White, S.D. and Morrison, G.L., 2016, A systematic parametric study and feasibility assessment of solar-assisted single-effect, double-effect, and triple-effect absorption chillers for heating and cooling applications. Energy Conversion and Management, 114, 258-277.

[23] Januševičius, K., Streckienè, G. and Misevičiūte, V., 2015, Simulation and analysis of small-scale solar adsorption cooling system for cold climate. International Journal of Environmental Science and Development, 6(1), 561.

[24] Molero-Villar, N., Cejudo-Lo’pez, J.M., Domı'nguez-Mun oz, J.M., Carrillo-Andre’s A., 2012, A comparison of solar absorption system configurations. Solar Energy, 86, 242-252.

[25] Monfet, D., Zmeureanu, R., 2009, Simulation of a large central cooling and heating plant using TRNSYS and calibration with monitored data. Eleventh International IBPSA Conference, Glasgow, Scotland, July 27-30.

[26] González-Gil, A., Izquierdo, M., Marcos, J.D. and Palacios, E., 2011, Experimental evaluation of a direct air-cooled lithium bromide-water absorption prototype for solar air conditioning. Applied Thermal Engineering, 1, 1-11.

[27] Eicker, U., Pietruschka, D., Haag, M. and Schmitt, A., 2015, Systematic design and analysis of solar thermal cooling systems in different climates. Renewable Energy, 80, 827-836.

[28] TRNSYS 17: A Transient Simulation Program. Solar Energy Lab (Madison, WI: University of Wisconsin).

[29] EES (Engineering Equation Solver), 2015, F-chart software, academic commercial V9. 941(19922015), www.fchart.com

[30] Deru, M., Torcellini, P., 2007, Source energy and emission factors for energy use in buildings, Technical Report NREL/TP-550-38617, June.

[31] Absortion Chiller suppliers, 2016. Available online at: http://www.alibaba.com/showroom/ absorption-chiller.html (accessed April 2016).

[32] Ontario Energy Board, 2016 Available online at: http://www.ontarioenergyboard.ca/oeb/ Consumers/Electricity/Electricity\%20Prices (accessed April 2016).

[33] RSB, 2016, New water and electricity tariffs structure regulation \& supervision bureau, http:// rsb.gov.ae/en/sector/new-water-and-electricity-tariffs-structure (accessed May 2016).

[34] Timothy K., 2008, Cooling water management: basic principles and technology, Technical report (Apache Junction, AZ, and Brockway, Pennsylvania: ProChemTech International, Inc). Available online at: http://www.prochemtech.com/Literature/Technical/Basic_Cooling_Water_ Management_II.pdf

[35] $\mathrm{CO}_{2}$ emission factor, Natural Resources Canada, Government of Canada, Available online at: http://www.nrcan.gc.ca/energy/efficiency/industry/technical-info/benchmarking/canadiansteel-industry/5193 (accessed 2017).

[36] Environment agency - Abu Dhabi: Greenhouse gas inventory, Inventory results, Executive summary, December 2012, Available online at: https://www.ead.ae/Documents/PDF-Files/ADGreenhouse-gas-inventory-Eng.pdf (accessed September 2017).

[37] Technical paper on federal carbon pricing backstop, Ministry of Environment and Climate Change Canada, Available online at: https://www.canada.ca/content/dam/eccc/documents/ pdf/20170518-2-en.pdf (accessed September 2017).

[38] The true cost of fossil fuels: Externality cost assessment methodology, International Renewable Energy Agency, Available online at: http://www.irena.org/DocumentDownloads/Publications/ IRENA_REmap_externality_methodology_2016.pdf (accessed September 2017).

[39] ASHRAE, HVAC system and equipment-Cooling Tower (Chapter-9), 2004, (Atlanta, Ca: American Society of Heating, Refrigeration and air-conditioning Engineers, Inc), http:// thermairsystems.com/wp-content/uploads/2011/10/ASHRAE-Systems-and-EquipmentCooling-Towers.pdf 